\title{
Teaching Software Engineering in Blended Learning
}

\author{
http://dx.doi.org/10.3991/ijep.v3iS2.2375 \\ Sharbani Bhattacharya \\ IEC College of Engineering \& Technology, Greater Noida, MTU Noida, India
}

\begin{abstract}
In this paper we will discuss teaching Software Engineering by using classroom teaching and web-based learning. The teaching assignments, notes, slides are also shared in a website while assessment is done one-to-one in viva or test conducted on the learning material. We are using Information and Communication Technology ICT for teaching. Software Engineering courseware are taught in B.Tech II year Information Technology and Computer Science \& Engineering course in Mahamaya Technical University (MTU), Noida (part of Uttar Pradesh Technical University (UPTU), Lucknow).
\end{abstract}

Index Terms-Web-based learning; blended learning; Teaching Software Engineering;

\section{INTRODUCTION}

Blended learning is effective way of teaching. Students are inspired to use various methods to gain, assess and realize the knowledge of the course content. We provoke students to be inquisitive on the topic so that we can give them appropriate information and ensure the knowledge on the subject matter by giving them marks, or credits or grade point. The assessment methodologies are sometimes controversial and always evolving. Assessment methodologies are appropriate time being. Teaching is an art of self evolving criteria which are never in the measurement. In this paper we will discuss teaching Software Engineering by using classroom teaching and web-based learning. The teaching assignments, notes , slides are also shared in a website while assessment is done one-to-one in viva or test conducted on the learning material.

Software Engineering course are taught in various ways. In traditional way where lectures lab works was given on start level. Next step is teaching the course in agile way. Here, students were more provided with practical situation and more effective way as most of the companies use agile Software Engineering[4]. Students are given learning pills on mobiles in innovative way of teaching and learning process[3]. There are various blended learning and e-learning methods. Reactive blended learning is found more useful in case of evaluation [21]. "The evaluation of the methodology was carried out in three categories:

- degree of learning and achievement of targeted skills.

- Degree of satisfaction with the proposal methodology.

- Performance of the student in the exam.

In three phases conventional methodologies BL, reactive BL and BL with motivation features are used.”[19]

\section{TEACHING SOFTWARE ENGINEERING}

The web-based learning along with classroom teaching benefits student online as well as offline. The courseware of Software Engineering is taught in B.Tech (IT) in IV semester. The course comprise of 40 lectures and 20 lab sessions. The course is offered by Uttar Pradesh Technical University, Lucknow at MTU Noida and GBTU Lucknow.

The site contents are

1. Syllabus, Question Bank

2. Assignments, Quizzes

3. Lectures, Notes,

4. Feedback Form

5. Important Links to SEI CMU

6. Important Links IEEE

7. Important Link to QAI

8. Books \& their Authors site

9. Teaching resource

10. Projects \& Instructions

11. Lab manuals

12. Important Links to journals and Masters Degree Programme

Syllabus , Question Bank, Assignment, Lecture notes are according to Syllabus in UPTU. Quizzes are innovative way of testing students. The quizzes in team or open book or writing exam like are used for assessment.

\section{IMPORTANT LINK TO SEI CMU}

Software Engineering Institute Carnegie Mellon University SEI CMU is key body which governs and standardize Software Engineering methodologies and technologies. The institute has given CMMI Levels for standardization of S/W companies. There are many conference, tutorials, workshop are conducted by Institute. It offers also courses on Master of Science (IT) \& (SEM) online degree. There are various slides, presentations and work are on the site. It is important that we should offer selected study material to the students which are given by professional organization. The professional organization overview and concepts should be learnt from beginning of the engineering education. The topic of discussion at the sites are Capability Maturity Model CMM Levels, SCAMPI, Quality Management, Risk Management, TSP(Team Software Process) and etc..

\section{IMPORTANT LINK TO QAI}

QAI Quality Assurance Institute offers various elearning courses which are beneficial for students for job and interview purpose. Students can do courses to add-on 
certificates. The benefits of choosing and identifying courses help in job prospects and practical application in real world.

\section{IMPORTANT LINK TO IEEE STANDARDS}

In the final semester students have to submit their projects. Generally, student make project which are more like novice. Keeping them in track with real world they should update with standards of preparing SRS, S/W Design ,S/W Architecture, Verification \& Validation, Testing CASE Tools, Maintenance \& Risk Management. Students are given exposure to IEEE standards. As it is expected that they should use standards for solving problems in lab. This gives an opportunity to know standards at II year and can be used in Final year project.

\section{PROJECTS \& LAB}

The lab work and manuals are given along with some projects. Students can try out the projects using standards of IEEE, ISO or CMM Level 3 of SEI CMU.

\section{BOOKS AND THEIR AUTHORS SITE}

In teaching it is always good to have access to teaching methodologies of other teachers. Books are important ingredient for learning process. Choice of Books and syllabus coverage reports are on easy access. The site of renowned authors along with their books give an insight to teacher as well as students on the topic. The links are given to Roger S Pressman's site, Somerville's Site and Pankaj Jalote's site. The learning materials, lab work , slide of books etc. are available in the site.

\section{TEACHING RESOURCES}

The site have teaching resources for teachers who can access course files, question banks, model test papers , lecture plans, syllabus coverage reports and etc.

\section{IMPORTANT LINKS TO JOURNALS}

It is important to tell students about journals and publication. Often telling them that this particular topic was published by this person in this journal helps students to remember the topic easily. Putting a picture of Pressman is an aid to memorize the topic given by Pressman. Links to IEEE Transaction on Software Engineering , ACM Transaction on Software Engineering \& Methodologies, ACM SigSoft, Elsevier Journal of System \& Software are given. Links to Springer Journals of Service Oriented Computing \& Applications, Journal of Software Engineering Research \& Development and Journal of Empirical Software Engineering. Link to the journal Innovation of System and Software Engineering by NASA is given.

\section{IMPORTANT LINKS TO E-LEARNING}

An E-Learning site is made by IIT \& IISc a joint venture where they have online lectures and study materials of Engineering most of the branches. NPTEL Phase I \& NPTEL Phase II have two different version of Software Engineering course. This is open access scheme and beneficial for students for basic knowledge and advanced concepts of Software Engineering.

\section{IMPORTANT LiNKS TO TECHNICAL SOCIETIES}

IEEE Computer Society Chapter has Technical Society Software Engineering TSSE. It is forum for professional discussion, organizing conferences, networking and jobs. There is link to SSE of RIT. Rochester Institute of Technology (RIT), New York has Society of Software Engineering for their students of BSEE. They are very active and have taken lot of initiative to be professional in the field of Software Engineering.

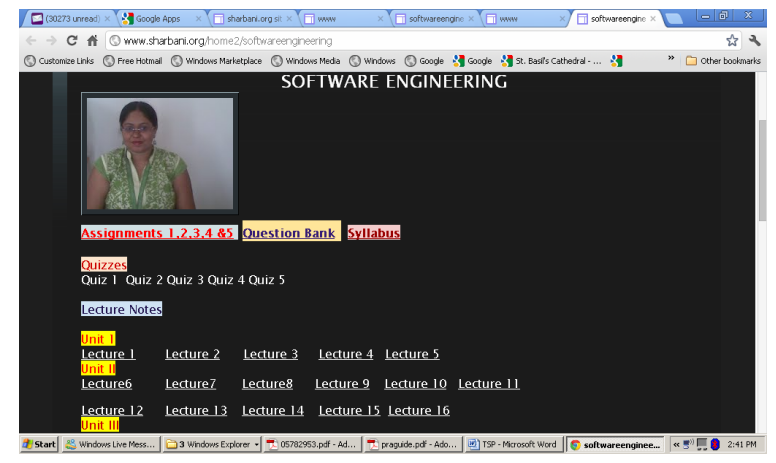

Figure 1. Question Banks, Quizzes \& Syllabus

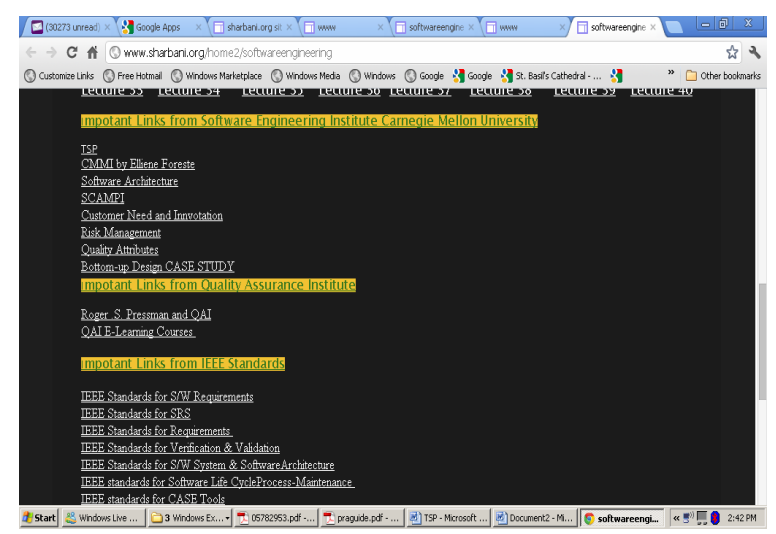

Figure 2. Links to SEI CMU, QAI and IEEE Standards

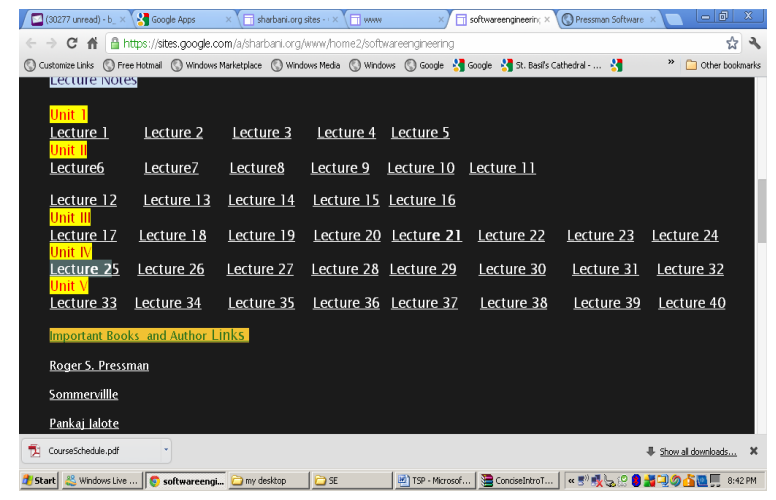

Figure 3. Lectures \& Books

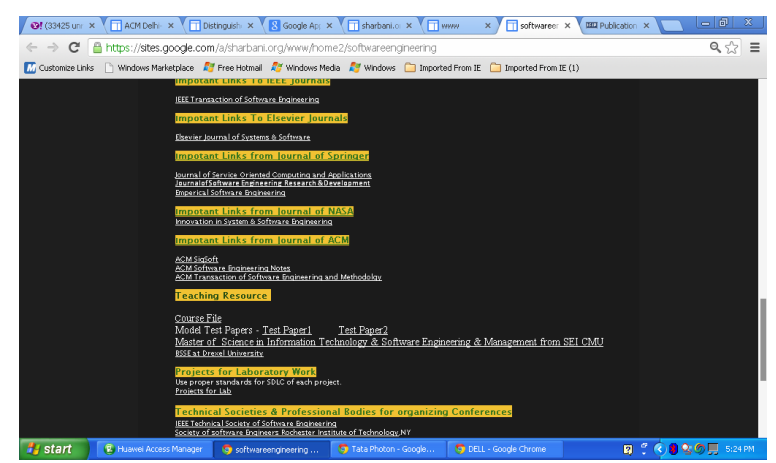

Figure 4. Teaching Resources, Journals \& Lab Works 


\section{SPECIAL FOCUS PAPER \\ TEACHING SOFTWARE ENGINEERING IN BLENDED LEARNING}

\section{CONCLUSION}

The concept of building the site on Software Engineering is to make students aware of important things happening in the real world in the profession. It is available in the internet but students should know which are relevant to their course. Selective links are aid to learning concepts. Taking quiz on learning materials enhance the interest and usefulness of the subject matter.

\section{REFERENCES}

[1] IEEE TRANSACTIONS ON EDUCATION, VOL. 54, NO. 2, MAY 2011 Page No. 229

[2] "The Key Factors of an Active Learning Method

[3] in a Microprocessors Course”,Antonio Carpeño, Jesús Arriaga, Javier Corredor, and Javier Hernández

[4] M. Prince, "Does active learning work? A review of the research," $J$.

[5] Eng. Educ., vol. 93, no. 3, pp. 223-231, 2004.

[6] IEEE TRANSACTIONS ON EDUCATION, VOL. 55, NO. 1, FEBRUARY 2012 Page No. 83 "Sending Learning Pills to Mobile Devices in class to Enhance Student Performance and Motivation in Network Services Configuration Courses" Mario MunozOrganero, PedroJ.Munoz merino and Carlos Delgado Kloos

[7] IEEE TRANSACTIONS ON EDUCATION, VOL. 55, NO. 1, FEBRUARY 2012 Page No. 99 "A capstone Course on Agile Software Development Using Scrum”, Viljan Mahnic

[8] IEEE TRANSACTIONS ON EDUCATION, VOL. 54, NO. 4, NOVEMBER 2011 Page No. 619 "Implementing motivational Feature in Reactive Blended Learning : Application to Introductory Control Engineering Course”, Juan Albino Mendez and Evelio. J. Gonzalez

[9] IEEE TRANSACTIONS ON EDUCATION, VOL. 54, NO. 4, NOVEMBER 2011 Page No. 610 "Trajectories of Electrical Engineering and Computer Engineering students by Race and Gender" , Susan M. Lord, Richard A. Layton and Mathew W. Ohland.

[10] IEEE TRANSACTIONS ON EDUCATION, VOL. 54, NO. 4, NOVEMBER 2011 Page N.o 590, "Edu Cloud: PaaS versus IaaS Cloud Usage for an Advanced Computer Science Course”, Luis M. Vaquero

[11] IEEE TRANSACTIONS ON EDUCATION, VOL. 54, NO. 4, NOVEMBER 2011 Page No. 576 "Automated Assessment in a Programming Tools Course” Jose Luis Fernandez Aleman.

[12] IEEE TRANSACTIONS ON EDUCATION, VOL. 54, NO. 4, NOVEMBER 2011 Page No. 564 "Validation of Symbloic Expressions in Circuit Analysis E-Learning”, Ludo Weyten , Pieter Rombouts, Benoits Catteau and Maarten De Bock

[13] IEEE TRANSACTIONS ON EDUCATION, VOL. 54, NO. 4, NOVEMBER 2011 Page No. 558 "A study of Computing Undergraduate Undertaking a Systematic Literature Review” Pearl Brereton.

[14] IEEE TRANSACTIONS ON EDUCATION, VOL. 54, NO. 3, AUGUST 2011 Page No. 374 "Evaluation of the Effectiveness of a Web-Based Learning Design for Adult Computer Science Courses”, K. Antonis, T. Daradoumis, S Papadakis, and C. Simos

[15] IEEE TRANSACTIONS ON EDUCATION, VOL. 54, NO. 3, AUGUST 2011 Page No. 381, "Teaching Multumedia Data Protection Through an International Online Competition”, F. Battisti, G. Boato, M. Carli and A. Neri

[16] IEEE TRANSACTIONS ON EDUCATION, VOL. 54, NO. 3, AUGUST 2011 Page No. 387 "Marrying Content and Process in Computer Science Education”, A. Zendler, C. Spannagel , and D. Klaudt.
[17] IEEE TRANSACTIONS ON EDUCATION, VOL. 54, NO. 3, AUGUST 2011 Page No. 398 "ADVICE -Educational System for Teaching Database Courses”, M Cvetanovic, Z Radivojevic and M. Bojovic.

[18] IEEE TRANSACTIONS ON EDUCATION, VOL. 54, NO. 3, AUGUST 2011 Page No. 416 "Game - Themed Programming Assignment Modules :A Pathway for Gradual Integration of Gaming Context into Existing Introductory Programming Courses”, K. Sung , C. Hillyard R.L. Angotti ,M. W. Panitz , D.S. Goldstein, and J. Nordlinger

[19] IEEE TRANSACTIONS ON EDUCATION, VOL. 54, NO. 3, AUGUST 2011 Page No. 442, "Student's Involvment in Continuous Assessment Methodologies: A Case Study for Distributed Information Systems Course”, M.D. Cano

[20] IEEE TRANSACTIONS ON EDUCATION, VOL. 54, NO. 3, AUGUST 2011 Page No. 471, “ How Blended Learning Reduces Underachievment in Higher Education :An Experience in Teaching Computer Science”, F. Alonso , D. Manrique ,L. Martinez and J.M. Vines

[21] IEEE TRANSACTIONS ON EDUCATION, VOL. 54, NO. 3, AUGUST 2011 Page No. 479, “ Computer Aided Teaching Using MATLAB /Simulink for Enhancing an IM Course With Laboratory Tests”, A. Bentousi, H Djeghloud ,H. Benalla, T. Birem and Amair

[22] IEEE TRANSACTIONS ON EDUCATION, VOL. 54, NO. 3 , AUGUST 2011 Page No. 501, " Effects of Response -Driven Feedback in Computer Science Learning”, J.L. Andujar, A. Mejias and M.A. Marquez.

[23] IEEE TRANSACTIONS ON EDUCATION, VOL. 55, NO. 1 , FEBRUARY 2012 Page No. 16, "The Use of Enhanced Guided Notes in an Electric Circuit Class : An Exploratory Study”, O. Lawanto.

[24] [21]JA Mendez and E.J. Gonzales , "A reactive blended learning proposal for an introductory control engineering course Comp. Educ Vol 54, 856-865 2010 http://dx.doi.org/10.1016/ j.compedu.2009.09.015

\section{AUTHOR}

Sharbani Bhattacharya is Associate Professor (Information Technology) in IEC-College of Engineering \& Technology Greater Noida, India. MS(Software Systems) BITS Pilani and M.Sc.(Mathematics) from Delhi University.

Research Interest and published work in Cryptography, Watermarking, Steganalysis, E-learning, Cloud Computing.

Senior Member of IEEE, Life Member \& Senior Member CSI and Member ACM, SEI Carnegie Mellon, IGIP Member. In IEEE Delhi Section-Secretary of IEEE Computational Intelligence Society, Treasurer IEEE Computer Society, Member of Workgroup of IEEE Standard Association for CASE TOOLS, System \& Software Engineering, Member of IEEE Education Society ,Signal Processing Society. Email Address: b_sharbani@yahoo.com

\section{Website: www.sharbani.org}

This article is an extended and modified version of a paper presented at the International Conference on Engineering Pedagogy (IGIP2012), held 26 - 28 September 2012, in Villach, Austria. Received 2 January 2013. Published as resubmitted by the authors 27 February 2013 